\title{
PENGARUH KOMPETENSI DAN STRES KERJA TERHADAP KINERJA PERAWAT DI RUMAH SAKIT JIWA PROVINSI BALI
}

\author{
I. G. D. Laksana', N. M. D. A. Mayasari² \\ 1,2 Jurusan Manajemen, Universitas Pendidikan Ganesha, Singaraja \\ e-mail: igddarmalaksana26@undiksha.ac.id¹, dwi.mayasari@undiksha.ac.id²
}

\begin{abstract}
Abstrak
Riset ini bermaksud untuk menguji peranan dari kompetensi serta stres kerja dari segi bersamaan dan sebagian atau terpisah terhadap kinerja perawat di RSJ Provinsi Bali. Rancangan riset yang digunakan adalah riset kuantitatif kausal. Sampel yang ditentukan dalam riset ini menggunakan metode proportionate sampling. Jumlah sampel yang dipakai sebanyak 104 responden. Instrumen yang dipakai saat menghimpun data adalah dengan cara observasi, pencatatan dokumen, dan cara penyebaran kuesioner, serta teknik analisa data yang dipakai yaitu analisis regresi linear berganda. Hasil riset menunjukkan: (1) Kompetensi serta stres kerja memiliki pengaruh penting untuk kinerja perawat pada RSJ Provinsi Bali. (2) Kompetensi memiliki peranan penting serta positif untuk kinerja perawat pada RSJ Provinsi Bali (3) Stres kerja memberikan peranan penting serta negatif untuk kinerja perawat pada RSJ Provinsi Bali.
\end{abstract}

Kata-kata kunci: kompetensi, stres kerja, dan kinerja perawat.

\begin{abstract}
This research intends to examine the role of competence and work stress in terms of simultaneously and partially or separately on the performance of nurses at RSJ Provinsi Bali. The research design used is causal quantitative research. The sample determined in this study used the proportionate sampling method. The number of samples used was 104 respondents. The instruments used when collecting data are by means of observation, recording documents, and distributing questionnaires, and the data analysis technique used is multiple linear regression analysis. The results showed: (1) Competence and work stress have an important influence on the performance of nurses at RSJ Provinsi Bali. (2) Competence has an important and positive role for the performance of nurses at RSJ Provinsi Bali (3) Job stress has an important and negative role for the performance of nurses at RSJ Provinsi Bali.
\end{abstract}

Keywords: competence, job stress, and nurse performance.

\section{Pendahuluan}

Rumah sakit adalah instrumen primer dalam memberikan pelayanan kesehatan yang mempunyai peran penting untuk kesehatan masyarakat. Rumah sakit diwajibkan agar bisa senantiasa menyediakan layanan maksimal untuk masyarakat yang membutuhkan layanan kesehatan. Rumah sakit perlu menperhatikan salah satu faktor dalam meyediakan layanan kesehatan yakni perawat (Faudin dkk, 2018). Perawat adalah suatu pekerjaan di rumah sakit yang mempunyai fungsi besar untuk upaya pemberian layanan kesehatan kepada masyarakat. Maka dari itu, rumah sakit yang mempekerjakan perawat selalu menjalankan beraneka ragam upaya yang bermaksud untuk mengoptimalkan mutu kecakapan perawat. Keperawatan adalah elemen utuh dari proses penyediaan layanan kesehatan yang menjadi unsur penting dalam memastikan kualitas layanan kesehatan. Oleh sebab itu, perlu dicermati performa perawat untuk melakukan kewajiban dan tanggung jawabnya dalam menyediakan layanan kesehatan untuk pasien (Aprilia, 2017).

Rumah Sakit Jiwa (RSJ) Provinsi Bali merupakan satu-satunya rumah sakit yang ada di Provinsi Bali yang menjadi central layanan kesehatan khususnya pada bidang pelayanan kesehatan jiwa, sehingga menjadi harapan utama masyarakat untuk mendapatkan pelayanan kesehatan jiwa yang berkualitas. Peningkatan pelayanan kesehatan jiwa menjadi tantangan bagi RSJ Provinsi Bali sesuai dengan visi rumah sakit yaitu sebagai pilihan pertama 
masyarakat di bidang layanan kesehatan jiwa, sehingga dituntut untuk memberikan pelayanan secara maksimal dengan selalu berorientasi kepada kepuasan pelanggan. Untuk itu sesuai dengan Peraturan Gubernur Bali Nomor 3 tahun 2016 mengenai standar pelayanan minimal pada RSJ Provinsi Bali dimana indikator kepuasan pelanggan menjadi salah satu standar pelayanan yang harus dapat dicapai dengan target capai minimal $85 \%$. Berdasarkan dari data capaian Standar Pelayanan Minimal (SPM) untuk indikator kepuasan pelanggan dalam kurun waktu tiga tahun terakhir yaitu 2017-2019 belum mencapai standar minimal yang ditargetkan dimana capaian SPM tahun 2017 sebesar 81,12\% kemudian menurun menjadi $80,65 \%$ pada tahun 2018 dan mencapai $80,05 \%$ pada tahun 2019.

Penilaian kinerja perawat pada RSJ Provinsi Bali menggunakan Ongoing Professional Practice Evaluation (OPPE) merupakan proses sistematis pengumpulan informasi kinerja praktik profesional perawat. Fungsi dan peran OPPE selaku media evaluasi kinerja profesional yang berkesinambungan disebabkan oleh tiga (3) alasan yaitu menjadi komponen dari usaha dalam mengawasi professional competence (kompetensi keahlian), menandai zona untuk peluang kenaikan kinerja, dan digunakan sebagai data faktual untuk ketetapan perihal kelangsungan kewenangan poliklinik. Adapun standar nilai kinerja karyawan yaitu kategori I 91 keatas sangat baik, kategori II 76-90 baik, kategori III 65-75 cukup, kategori IV 51-64 kurang, dan kategori $\bigvee 50$ ke bawah.

Berdasarkan hasil evaluasi kinerja perawat pada RSJ Provinsi Bali tahun 2017 nilai ratarata kinerja perawat adalah $81,5 \%$ dan masuk dalam kategori baik, kemudian tahun 2018 menurun menjadi 78,5\% dan masih masuk dalam kategori baik, akan tetapi pada tahun 2019 terjadi penurunan kinerja menjadi $74,3 \%$ dan menyebabkan kinerja masuk dalam kategori cukup. Mengetahui perawat menjadi Sumber Daya Manusia (SDM) yang memiliki peran besar dalam memberikan layanan kesehatan di rumah sakit tanpa harus mengesampingkan peran dan arti SDM lainnya, oleh sebab itu kinerja perawat perlu menjadi prioritas dalam perbaikan untuk peningkatan kualitas pelayanan.

Kinerja atau performance adalah output yang diciptakan dari peranan dan parameter satu pekerjaan untuk jangka waktu yang telah ditentukan (Kurniadi A, 2013). Gibson (dalam llyas, 2012) mengungkapkan bahwa performa tenaga perawat mempunyai dampak besar untuk terbentuknya kualitas layanan kesehatan yang maksimal dan berkualitas, dikarenakan perawat adalah pembentuk kesan awal serta paling lama bersama pasien, oleh sebab itu perawat adalah figur yang bisa mewakili segala image atau tampilan rumah sakit.

Menurut Simanjuntak (2018) aspek-aspek yang membentuk kinerja merupakan aspek dari faktor personal yaitu skill (kemampuan), background (latar belakang), daerah tinggal serta disiplin. aspek lain seperti unsur psikis diantaranya pemahaman, perilaku, watak, dorongan, rasa puas dalam bekerja serta beban pekerjaan. Aspek terakhir merupakan aspek organisasi diantaranya sifat pemimpin, imbalan, masalah, kekuatan, desain organisasi, sistem kerja, budaya kerja, komitmen institusi dan program kompensasi. Faktor kompentensi merupakan salah satu dari variabel individu yang bisa mengukur tingkat kinerja, Mangkunegara (2008) mengungkapkan teori yaitu keterkaitan kompetensi dan kinerja ialah begitu kuat serta sangat penting, ada keterkaitan yang logis dan jelas, apabila pegawai hendak memaksimalkan performanya sebaiknya memiliki kemampuan atau kompetensi yang sejalan dengan kewajiban dan tanggung jawab pekerjaan. Kemudian hal lain yang bisa mengukur tingkat kinerja ialah stres kerja, Umam (2010) mengungkapkan bahwa taraf stres kerja yang berat dan stres ringan berkelanjutan bisa menurunkan kinerja pegawai.

Kinerja pegawai rumah sakit khusunya perawat di Indonesia masih rendah. Penelitian Maslita (2017) di ruang rawat inap RSU Kabupaten Tangerang menunjukkan kinerja perawat masih cukup kecil hanya berkisar 53,7\%. Riset yang dilakukan Rahmat (2018) masih menunjukkan capaian kinerja perawat yang masih cukup kecil hanya berkisar $50 \%$. Kemudian riset dari Maulani dan Dasuki (2018) lagi-lagi menunjukkan kinerja perawat dengan kategori rendah berkisar $47,6 \%$. Jika diamati hasil penelitian menunjukkan kinerja perawat berada dalam kategori rendah hanya berkisar $50 \%$, ini menunjukkan secara umum pelayanan kesehatan yang diberikan perawat kepada pasien belum maksimal. Hasil memperlihatkan kinerja adalah instrumen utama yang perlu mendapatkan perhatian dari pihak manajer/atasan 
supaya layanan kesehatan yang diberikan oleh perawat dapat maksimal dan sesuai dengan standar serta harapan masyarakat.

Kompetensi atau dalam bahasa inggris competence, memiliki makna keterampilan, kewenangan dan keahlian. Kompetensi dari sisi asal-usul kata bermakna sisi kelebihan, kecakapan sikap individu atau seseorang yang memiliki kecerdasan, sikap dan keterampilan. Ciri kompetensi yakni suatu hal yang dijadikan komponen dari ciri pribadi dan dijadikan komponen dari sikap individu saat melakukan kewajiban dan tanggung jawab dalam bekerja (Mangkunegara, 2008). Kompetensi perawat adalah keterampilan perawat dalam melaksanakan praktik keperawatan selaras dengan wawasan, kemampuan, perilaku serta pengukuran berlandaskan basic education (pendidikan dasar) serta maksud tindakan keperawatan yang dievaluasi sejalan dengan kinerja perawat. Bertujuan agar terus konsisten mempertahankan mutu kesehatan serta keselamatan pasien (Bartlett dkk, 2010). Hasil penelitian Sanjaya dkk (2016) menunjukkan kompetensi memiliki peranan penting serta positif untuk kinerja perawat di Rumah Sakit Umum di Makassar. Hasil berbeda (research gap) didapatkan oleh penelitian Nurlaila dkk (2016) menemukan kompetensi tidak memiliki peranan penting untuk kinerja paramedis pada Puskesmas Caile Kabupaten Bulukumba.

Menurut Mangkunegara (2013) stres kerja merupakan ketidaknyamanan pikiran yang dihadapi pekerja saat diberikan tugas pekerjaan. Stres kerja memberi pengaruh perasaan menjadi labil, sering mengasingkan diri, susah untuk tidur, serta mengalami masalah kesehatan seperti masalah pencernaan. Chairani (2009) mengungkapkan stres kerja perawat merupakan situasi dimana perawat merasakan ketidaknyamanan disebabkan oleh pekerjaan yang bisa menciptakan ketegangan di lingkungan pekerjaan terdiri dari aspek fisik, psikis, dan sikap dalam bekerja. Tyczkowski dkk (2015) mengungkapkan bila perawat merasakan stres bisa berpengaruh buruk terhadap perilaku yang tidak profesional dalam bekerja. Stres menimbulkan perasaan yang cepat berubah-ubah. Perasaan yang berubah-ubah bisa mengakibatkan terjadinya tindakan-tindakan yang tidak semestinya. Perasaan yang cepat berubah-ubah adalah tanda-tanda psikis dari dampak stres kerja bisa menjadi penghambat karir serta kinerja perawat disebabkan motivasi yang berkurang untuk bekerja. Riset dari Fauzan (2017) menemukan stres kerja mempunyai peranan penting serta negatif untuk kinerja perawat di RSUD Pematang Siantar. Hasil berbeda (research gap) didapatkan oleh hasil penelitian Faudin dkk (2018) yang menemukan ada peranan penting serta positif stres kerja untuk kinerja perawat.

Kaitan logis dari kompetensi dan stres kerja dengan kinerja dijelaskan oleh teori dari Robbins (2003) yang menyatakan apabila karyawan mempunyai kemampuan atau kompetensi dalam bekerja dapat menolong karyawan untuk menangani stres dengan cermat yang akan membentuk situasi kerja menggairahkan sehingga berdampak pada kinerja karyawan. Dengan demikian ada pengaruh kompetensi dan stres kerja terhadap kinerja karyawan. Teori ini sejalan dengan hasil penelitian yang dilaksanakan Suka dkk (2019) menunjukkan kompetensi dan stres kerja mempunyai peranan penting untuk kinerja pegawai. Kemudian hasil riset Sitompul dkk (2018) juga menyatakan kompetensi dan stres kerja mempunyai peranan penting untuk kinerja pegawai. $\mathrm{H}_{1}$ : Ada pengaruh secara simultan kompetensi dan stres kerja terhadap kinerja perawat pada RSJ Provinsi Bali.

Tinggi rendahnya kompetensi yang karyawan miliki akan berdampak pada kinerja yang dihasilkan karyawan. Dengan karyawan yang kompeteten, maka perusahaan akan semakin kompetitif dan mampu bersaing untuk tetap menjaga eksistensinya. Kompetensi perawat adalah keterampilan perawat dalam melaksanakan praktik keperawatan selaras dengan wawasan, kemampuan, perilaku serta pengukuran berlandaskan basic education (pendidikan dasar) serta maksud tindakan keperawatan yang dievaluasi sejalan dengan kinerja perawat. Bertujuan agar terus konsisten mempertahankan mutu kesehatan serta keselamatan pasien (Bartlett dkk, 2010). Mangkunegara (2008) mengungkapkan teori yaitu keterkaitan kompetensi dan kinerja ialah begitu kuat serta sangat penting, ada keterkaitan yang logis dan jelas, apabila pegawai hendak memaksimalkan performanya sebaiknya memiliki kemampuan/kompetensi yang sejalan dengan kewajiban dan tanggung jawab pekerjaan. Hal tersebut sejalan dengan riset dari Sanjaya dkk (2016) yang menunjukkan kompetensi mempunyai peranan penting serta positif untuk kinerja pegawai. Kemudian riset dari Prayogi 
dkk (2019) juga menyatakan kompetensi mempunyai peranan penting untuk kinerja karyawan. $\mathrm{H}_{2}$ : Ada pengaruh parsial kompetensi terhadap kinerja perawat pada RSJ Provinsi Bali.

Stres merupakan situasi yang acap kali dialami oleh karyawan, maka dari itu, stres kerja harus dicermati dengan serius agar tidak mempengaruhi kinerja yang dihasilkan karyawan untuk organisasi. Menurut Mangkunegara (2013) stres kerja merupakan ketidaknyamanan pikiran yang dihadapi pekerja saat diberikan tugas pekerjaan. Stres kerja memberi pengaruh perasaan menjadi labil, sering mengasingkan diri, susah untuk tidur, serta mengalami masalah kesehatan seperti masalah pencernaan. Chairani (2009) mengungkapkan stres kerja perawat merupakan situasi dimana perawat merasakan ketidaknyamanan disebabkan oleh pekerjaan yang bisa menciptakan ketegangan di lingkungan pekerjaan terdiri dari aspek fisik, psikis, dan sikap dalam bekerja. Tyczkowski dkk (2015) mengungkapkan bila perawat merasakan stres bisa berpengaruh buruk terhadap perilaku yang tidak profesional dalam bekerja. Stres menimbulkan perasaan yang cepat berubah-ubah. Perasaan yang berubahubah bisa mengakibatkan terjadinya tindakan-tindakan yang tidak semestinya. Perasaan yang cepat berubah-ubah adalah tanda-tanda psikis dari dampak stres kerja bisa menjadi penghambat karir serta kinerja perawat disebabkan motivasi yang berkurang untuk bekerja. Kemudian Umam (2010) mengungkapkan bahwa taraf stres kerja yang berat dan stres ringan berkelanjutan bisa menurunkan kinerja pegawai. Teori ini sesuai dengan hasil riset yang dilaksanakan Fauzan (2017) yang menemukan stres mempunyai peranan penting serta negatif untuk kinerja pegawai. Kemudian hasil penelitian Monika (2017) juga menyatakan stres kerja mempunyai peranan penting serta negatif untuk kinerja pegawai. $\mathrm{H}_{3}$ : Ada peranan parsial stres kerja terhadap kinerja perawat pada RSJ Provinsi Bali.

Adapun tujuan dalam riset ini ialah mendapatkan penjabaran meyakinkan tentang pengaruh: (1) Kompetensi dan stres kerja terhadap kinerja perawat pada RSJ Provinsi Bali. (2) Kompetensi terhadap kinerja perawat pada RSJ Provinsi Bali. (3) Stres kerja terhadap kinerja perawat pada RSJ Provinsi Bali.

\section{Metode}

Jenis penelitian yang dipergunakan merupakan penelitian kuantitatif. Rancangan penelitian yang dipergunakan di dalam penelitian ini ialah rancangan penelitian kausal. Rancangan kausal digunakan untuk mempelajari hubungan sebab dan akibat antar variabel yang memberi pengaruh dengan variabel yang mendapatkan pengaruh (Sugiyono, 2014). Variabel independent (bebas) yang dipakai pada riset ini meliputi: kompetensi $\left(\mathrm{X}_{1}\right)$, stres kerja $\left(\mathrm{X}_{2}\right)$. Sedangkan variabel dependent (terikat) yang digunakan ialah Kinerja perawat $(\mathrm{Y})$. Langkah-langkah dalam rancangan penelitian kuantitatif kausal meliputi (1) menjelaskan masalah, (2) mempelajari teori, (3) merumuskan hipotesis, (4) menghimpun data, (5) menganalisa data, serta (6) membuat simpulan.

Riset ini memakai (3) tiga variabel meliputi (2) dua variabel independent (bebas) yaitu kompetensi dan stres kerja serta (1) satu variabel dependent (terikat) yaitu kinerja perawat. Subjek dalam penelitian ini adalah seluruh perawat pelaksana RSJ Provinsi Bali. Sedangkan yang digunakan sebagai objek dalam riset ini ialah kompetensi (X1), stres kerja (X2) serta kinerja perawat $(Y)$. Populasi pada riset ini merupakan semua perawat pelaksana yang bekerja pada ruangan rawat inap RSJ Provinsi Bali yang berjumlah 140 menggunakan uraian 88 perawat pada ruangan rawat inap dewasa serta 52 perawat di ruangan rawat inap khusus. Total sampel dalam penelitian adalah sebanyak 104 perawat. Penentuan sampel dilakukan merata di tiap-tiap ruangan, menggunakan rincian 65 perawat di ruangan rawat inap dewasa dan 39 perawat di ruangan rawat inap khusus. Pengumpulan data dilakukan menggunakan metode observasi, mencatat dokumen/arsip serta metode kuesioner, serta teknik analisa menggunakan analisis regresi linear berganda. Supaya bisa melakukan prosedur penganalisisan data dengan efektif serta efisien, Oleh sebab itu penganalisisan data dilaksanakan dengan menggunakan program Statistikal Package for the Social Science (SPSS) versi 23. 


\section{Hasil dan Pembahasan}

Hasil dari analisis regresi linear berganda memakai program Statistikal Package for the Social Science (SPSS) versi 23 diperoleh temuan sebagai berikut.

Tabel I

Output Analisis Regresi Linear Berganda

\begin{tabular}{|c|c|c|c|c|c|}
\hline Pengukuran & Nilai & P-Value & $\begin{array}{c}\text { Alpha } \\
(\alpha)\end{array}$ & Ketetapan & Kesimpulan \\
\hline $\mathrm{F}_{\text {hitung }}>\mathrm{F}_{\text {tabel }}$ & $25,584>3,09$ & 0,000 & 0,05 & $\begin{array}{c}\text { Menerima } \\
\mathrm{H} 1\end{array}$ & $\begin{array}{l}\text { Terdapat peranan } \\
\text { penting kompetensi } \\
\text { dan stres kerja } \\
\text { untuk kinerja } \\
\text { perawat. }\end{array}$ \\
\hline $\mathrm{Pyx}_{1}$ & 0,555 & 0.000 & 0.05 & $\begin{array}{l}\text { Menerima } \\
\mathrm{H} 2\end{array}$ & $\begin{array}{l}\text { Terdapat peranan } \\
\text { penting kompetensi }\end{array}$ \\
\hline & & & & & $\begin{array}{l}\text { untuk kinerja } \\
\text { perawat. }\end{array}$ \\
\hline $\mathrm{Pyx}_{2}$ & $-0,533$ & 0.000 & 0.05 & $\begin{array}{l}\text { Menerima } \\
\text { H3 }\end{array}$ & $\begin{array}{l}\text { Ada peranan } \\
\text { penting dari stres } \\
\text { kerja untuk kinerja } \\
\text { perawat. }\end{array}$ \\
\hline
\end{tabular}

Sumber: Data diolah pada SPSS

Struktur hubungan pengaruh kompetensi $\left(X_{1}\right)$ dan stres kerja $\left(X_{2}\right)$ terhadap kinerja perawat $(\mathrm{Y})$ yaitu bisa diamati dari Gambar I berikut:

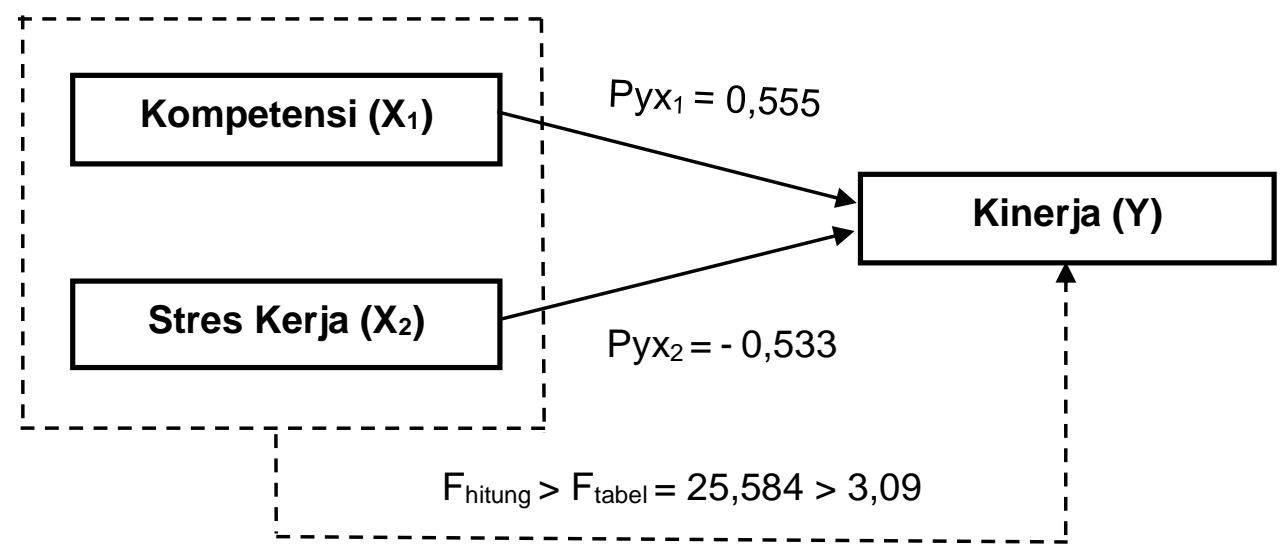

Hipotesis penelitian pertama "Terdapat pengaruh kompetensi dan stres kerja terhadap kinerja perawat di RSJ Provinsi Bali”. Bersumber dari output pengujian regresi linear berganda pada Tabel I menampilkan output Fhitung $>$ Ftabel $=25,584>3,09$ dengan $p$-value $=0,000$ lebih kecil dari alpha $(\alpha)=0,05$. Hasil ini menunjukkan secara simultan kompetensi dan stres kerja memiliki peran penting untuk kinerja perawat. bisa dikatakan variabel kompetensi dan stres kerja dengan simultan berperan dalam meningkatkan kinerja perawat.

Hipotesis riset kedua "Ada pengaruh kompetensi terhadap kinerja perawat di RSJ Provinsi Bali". Berdasarkan output pengujian regresi linear berganda dari Tabel I menunjukkan output $P y x 1=0,555$ dengan $p$-value 0,000 lebih kecil dari alpha $(\alpha)=0,05$. Hasil memperlihatkan variabel kompetensi mempunyai peran penting dan positif untuk kinerja perawat. Dapat dinyatakan kompetensi berperan dalam meningkatkan kinerja perawat.

Hipotesis penelitian ketiga "Ada pengaruh secara parsial stres kerja terhadap kinerja perawat di RSJ Provinsi Bali”. Berlandaskan output pengujian analisis regresi dari Tabel I 
menampilkan output Pyx2 $=-0,533$ dengan p-value 0,000 lebih kecil dari alpha $(\alpha)=0,05$. Hasil ini menunjukkan variabel stres kerja memberikan peran negatif dan penting untuk kinerja perawat. Bisa dinyatakan stres kerja berperan dalam menurunkan kinerja perawat.

Berdasarkan penelitian, output pengujian regresi linear berganda menunjukkan Fhitung $>$ Ftabel $=25,584>3,09$ dengan $p$-value $=0,000<$ alpha $(\alpha)=0,05$, hasil menunjukkan variabel bebas yaitu kompetensi dan stres kerja mempunyai peran penting untuk kinerja perawat di RSJ Provinsi Bali. Hasil pengujian ini menunjukkan bahwa Hipotesis I yang mengatakan terdapat peran secara bersama-sama kompetensi dan stres kerja untuk kinerja perawat di RSJ Provinsi Bali diterima. Hasil ini sejalan dengan teori Robbins (2003) menyatakan apabila karyawan mempunyai kemampuan atau kompetensi dalam bekerja dapat menolong karyawan untuk menangani stres dengan cermat yang akan membentuk situasi kerja menggairahkan sehingga berdampak pada kinerja karyawan. Dengan demikian ada pengaruh kompetensi dan stres kerja terhadap kinerja karyawan. Hal tersebut sejalan dengan riset yang dilaksanakan Sitompul dkk (2018), Suka dkk (2019) dan Rangkuti dkk (2020) yang menyatakan kompetensi serta stres kerja memberikan peran signifikan untuk kinerja karyawan.

Kompetensi adalah variabel yang bisa memberikan pengaruh untuk kinerja perawat. Salah satu cara untuk mengukur tingkat kompetensi perawat adalah dilihat taraf atau tingkat pendidikan, hampir semua perawat di RSJ Provinsi Bali memiliki tingkat pendidikan S. Kep + Ners yang menjadi standar dan tolak ukur bahwa perawat sudah mempunyai kompetensi yang cukup baik. Melalui kompetensi yang baik perawat akan mampu memberikan pelayanan terbaik kepada pasien. Stres dapat dialami oleh semua orang, tidak terkecuali perawat. Banyak faktor yang dapat memicu terjadinya stres, contohnya seperti masalah pekerjaan dan masalah keluarga. Pihak Rumah Sakit Jiwa Provinsi Bali diharapkan memberikan perhatian lebih terhadap tingkat stres yang dialami oleh para perawat, karena tingkat stres yang berlebihan bisa berakibat pada penurunan kinerja dan pelayanan perawat kepada pasien. Tindakan atau usaha yang bisa dilaksanakan oleh pihak RSJ Provinsi Bali adalah dengan melakukan upaya mempertahankan dan peningkatan kompetensi kerja serta melakukan manajemen atau pengendalian stres kerja perawat yang baik dan benar sehingga perawat dapat menghasilkan kinerja dan pelayanan optimal kepada pasien sejalan dengan parameter yang telah ditentukan dari RSJ Provinsi Bali.

Berdasarkan penelitian, output pengujian regresi linear berganda menunjukkan Pyx1 = 0,555 dengan $p$-value $=0,000<$ alpha $(\alpha)=0,05$, hasil menunjukkan bahwa variabel bebas kompetensi memiliki peranan penting serta positif untuk kinerja perawat pada RSJ Provinsi Bali. Output pengujian menunjukkan bahwa hipotesis II yang menyatakan ada pengaruh sebagian kompetensi untuk kinerja perawat pada RSJ Provinsi Bali diterima. Hasil sesuai dengan teori Mangkunegara (2008) yang mengungkapkan keterkaitan kompetensi dan kinerja ialah begitu kuat serta sangat penting, ada keterkaitan yang logis dan jelas, apabila pegawai hendak memaksimalkan performanya sebaiknya memiliki kemampuan atau kompetensi yang sejalan dengan kewajiban dan tanggung jawab pekerjaan. Kemudian menurut Siregar dkk (2019) Kompetensi adalah variabel yang mempengaruhi pegawai dalam menghasilkan kinerja istimewa saat bekerja. Hal tersebut sejalan dengan hasil penelitian Sanjaya dkk (2016), Prayogi dkk (2019) dan Suwandika dkk (2019) yang menyatakan kompetensi mempunyai peranan penting serta positif untuk kinerja karyawan.

Tingkat kompetensi yang dimiliki seorang perawat sangat mempengaruhi tinggi rendahnya kinerja yang dihasilkan. Sebagian besar perawat pada RSJ Provinsi Bali memiliki tingkat pendidikan S. Kep + Ners yang menjadi standar dan tolak ukur bahwa kompetensi yang dimiliki perawat saat ini sudah cukup baik. Melalui kompetensi yang melekat pada diri perawat dengan begitu diharapkan perawat bisa menyelenggarakan suatu proses kerja yang terukur serta dapat memberikan performa yang maksimal, serta pasien dan keluarga pasien dapat merasakan kepuasan melalui layanan yang diberikan perawat di RSJ Provinsi Bali. Seorang perawat semestinya mampu untuk mempertahankan serta melakukan peningkatan terhadap keterampilan yang dipunyai saat melakukan tugas kerja, serta perilaku perawat saat memberikan pelayanan kepada pasien semestinya tetap sopan dan santun, sehingga pasien merasakan sebuah kenyamanan saat menerima perawatan kesehatan yang diberikan oleh 
perawat. Tindakan atau usaha yang bisa dilaksanakan pihak RSJ Provinsi Bali adalah dengan melakukan upaya mempertahankan serta meningkatkan kompetensi kerja perawat, seperti memperbanyak kegiatan pelatihan dan praktik keperawatan secara berkesinambungan dan berkelanjutan sehingga perawat tetap bisa konsisten dalam memberikan kinerja dan pelayanan terbaik kepada pasien.

Berdasarkan penelitian, output pengujian regresi linear berganda menunjukkan Pyx2 = - 0,533 dengan $p$-value $=0,000<$ alpha $(\alpha)=0,05$, hasil menunjukkan variabel bebas stres kerja memberikan peranan penting serta negatif untuk kinerja perawat di RSJ Provinsi Bali. Hasil pengujian menunjukkan hipotesis III yang mengatakan terdapat pengaruh secara parsial stres kerja untuk kinerja perawat pada RSJ Provinsi Bali diterima. Hal ini sejalan dengan teori Umam (2010) yang mengungkapkan bahwa taraf stres kerja yang berat dan stres ringan berkelanjutan bisa menurunkan kinerja pegawai. Hal tersebut didukung dengan hasil penelitian Fauzan (2017), Monika (2017) dan Aprilia (2017) yang menyatakan variabel stres kerja memberikan peranan penting serta negatif untuk kinerja karyawan.

Pihak RSJ Provinsi Bali diharapkan memberikan perhatian lebih terhadap tingkat stres yang dialami oleh para perawat, karena tingkat stres yang berlebihan bisa berakibat pada penurunan kinerja perawat. Hal ini memberikan makna bahwa taraf atau level stres yang berat akan berdampak pada keadaan mental serta fisik seorang perawat. Tingkat stres kerja ringan mungkin masih belum mempengaruhi kinerja dari seorang perawat, namun jika stres kerja yang dialami begitu berat, kinerja perawat lambat laun akan menurun disebabkan gangguan dari stres kerja pada saat bekerja. Perawat yang memiliki stres kerja sedang dan berat akan kehilangan kemampuan dan motivasi dalam bekerja dan lebih buruknya perawat memilih resign atau mengundurkan diri karena merasa tidak mampu lagi untuk bekerja. Perawat yang mengalami stres kerja sedang dan berat cenderung mengalami penurunan kemampuan dalam bekerja yang akan berdampak pada penurunan kinerja perawat. Tindakan atau usaha yang bisa dilaksanakan pihak RSJ Provinsi Bali adalah dengan melakukan pengendalian atau manajemen stres kerja yang baik dan benar bagi para perawat. Beberapa cara yang bisa dilakukan, seperti memberikan kegiatan olahraga dan meditasi minimal satu kali dalam seminggu agar perawat bisa merasa relax dalam bekerja, kemudian cara selanjutnya dengan membuat hubungan kerja antar perawat semakin erat sebagai sebuah tim, sehingga perawat merasa tidak sendiri dalam bekerja. Dengan pengendalian atau manajemen stres kerja yang baik dan benar diharapkan nantinya perawat tetap bisa memberikan pelayanan dan kinerja maksimal kepada pasien.

\section{Simpulan dan Saran}

Berlandaskan output serta penjabaran yang dilakukan, jadi bisa simpulan dalam penelitian ini adalah sebagai berikut. (1) Kompetensi dan stres kerja memiliki pengaruh penting untuk kinerja perawat pada RSJ Provinsi Bali. (2) Kompetensi mempunyai peranan penting serta positif untuk kinerja perawat pada RSJ Provinsi Bali. (3) Stres kerja mempunyai peranan penting serta negatif untuk kinerja perawat pada RSJ Provinsi Bali.

Berlandaskan output dari penjabaran serta tiap-tiap simpulan dalam riset ini, berikut saran-saran yang bisa dicantumkan dari output riset supaya nantinya mendapat output yang lebih sempurna yaitu sebagai berikut. (1) Untuk peneliti berikutnya, semestinya dapat mengembangkan penelitian ini dengan menambahkan faktor-faktor lain yang mempengaruhi kinerja perawat, mengembangkan subjek penelitian, memperbanyak teori-teori tentang variabel yang digunakan, menggunakan teknik analisis data yang lain agar dapat menjadi acuan dari penelitian-penelitian selanjutnya serta dapat menambah ilmu pengetahuan khusunya pada bidang MSDM. (2) Untuk RSJ Provinsi Bali, diharapkan dapat mempertahankan dan meningkatkan kompetensi perawat pada masa sekarang dan untuk kedepannya. Selain itu manajemen atau pengendalian stres kerja perawat yang baik dan benar juga perlu mendapatkan perhatian lebih, agar nantinya stres kerja yang dimiliki perawat tidak mengganggu pelayanan serta performa yang diberikan oleh perawat pada RSJ Provinsi Bali. 


\section{Daftar Pustaka}

Aprilia, Friska. 2017. "Pengaruh Beban Kerja, Stres Kerja dan Motivasi Kerja terhadap Kinerja Perawat Rumah Sakit Islam Ibnu Sina Pekanbaru”. Pekanbaru: Universitas Riau.

Bartlett, John G dkk. 2010. Practice Guidelines for the Management of Community-Acquired Pneumonia in Adults. America: Clinical Infectious Diseases Society of America.

Bidang Perawatan Rumah Sakit Jiwa Provinsi Bali. 2019. Penilaian Kinerja Perawat. Bangli : Rumah Sakit Jiwa Provinsi Bali.

Chairani, Meylinda. F \& Budiharto, Sus. 2009. "Hubungan antara Komunikasi Interpersonal dengan Stres Kerja pada Perawat". Yogyakarta: Universitas Islam Indonesia Yogyakarta.

Faudin, Mokhamad Afif dkk. 2018. "Pengaruh Stres Kerja terhadap Kinerja Perawat melalui Kepuasan Kerja”. Malang: Universitas Wisnuwardhana Malang.

Fauzan, Muhammad. 2017. "Pengaruh Stres dan Kepemimpinan terhadap Kinerja Perawat di Rumah Sakit Umum Daerah Pematangsiantar". Pematangsiantar: STIKOM Tunas Bangsa.

Ilyas, Yaslis. 2012. Perencanaan SDM Rumah Sakit. Jakarta: FKM UI.

Kurniadi, Anwar. 2013. "Pengaruh Kompetensi dan Beban Kerja terhadap Kinerja Pelaksanaan Asuhan Keperawatan pada Bagian Rawat Inap Rumah Sakit Umum Dr Slamet Garut". Garut: Universitas Garut.

Mangkunegara, Anwar Prabu. 2008. Evaluasi Kinerja Sumber Daya Manusia, Cetakan Pertama. Bandung: PT. Refikaditama.

Mangkunegara, Anwar Prabu. 2013. "Hubungan Stres Kerja dengan Kinerja Perawat Pelaksana di RSU Bina Kasih Medan Tahun 2017". Sumatera Utara: Universitas Sumatera Utara.

Maslita, Karen. 2017. "Gambaran Kinerja Perawat Pelaksana di Ruang Rawat Inap RSU Kabupaten Tangerang". Jakarta: Universitas Islam Negeri Syarif Hidayatullah Jakarta.

Maulani dan Dasuki. 2018. "Hubungan Pendidikan, Motivasi Kerja, Supervisi Kepala Ruangan dengan Kinerja Perawat RSUD Hanafie Muara Bungo". Jambi: STIKES Harapan Ibu.

Monika, Sinta. 2017. "Beban Kerja dan Stres Kerja terhadap Kinerja Karyawan pada PT. Galamedia Bandung Perkasa". Bandung: Universitas Komputer Indonesia

Peraturan Gubernur Bali Nomor 3 Tahun 2016. Budaya Kerja pada Pemerintah Provinsi Bali. Bali: Biro Organisasi.

Prayogi, Muhammad Andi dkk. 2019. "Pengaruh Kompetensi dan Disiplin Kerja tterhadap Kinerja Pegawai". Sumatera Utara: Universitas Muhammadiyah Sumatera Utara.

Rahmat, Hidayat. 2018. "Hubungan Faktor Stres Kerja dengan Kinerja Perawat di Instalasi Gawat Darurat di Rumah Sakit Surabaya". Surabaya: Rumah Sakit Surabaya.

Rangkuti, Dhita Adriani dkk. 2020. "Pengaruh Kompetensi, Komunikasi dan Stres Kerja Terhadap Kinerja Karyawan pada PT Himawan Putra Medan”. Medan: Universitas Prima Indonesia.

Robbins, Stephen P. 2003. "Pengaruh Kompetensi dan Stres Kerja terhadap Kinerja Pegawai pada Dinas Pendidikan Nasional Provinsi Sulut". Sulawesi Utara: Universitas Sam Ratulangi Manado

Sanjaya, Hendi dkk. 2016. "Pengaruh Kompetensi dan Motivasi terhadap Kinerja Perawat pada Dokumentasi Asuhan Keperawatan di Ruang Rawat Inap RSU Wisata Universitas Indonesia Timur Makassar". Makassar: Universitas Indonesia Timur Makassar. 
Simanjuntak, Payaman J. 2018. Manajemen dan Evaluasi Kinerja. Jakarta: Fakultas Ekonomi Universitas Indonesia.

Siregar, Winda Peronika dkk. 2019. "Pengaruh Kompetensi dan Stres Kerja terhadap Kinerja Karyawan pada PT. Pioneerindo Gourmet Internasional, Tbk. Medan". Medan: Universitas Prima Indonesia.

Sitompul, Putri Ulina dkk. 2018. "Pengaruh Stres Kerja dan Kompetensi terhadap Kinerja Karyawan pada PT. Jasa Harapan Barat". Medan: Universitas Prima Indonesia.

Sugiyono. 2014. Metode Penelitian Bisnis. Bandung: Alfabeta.

Suka, Herry Ginting dkk. 2019. "Pengaruh Kompetensi dan Stres Kerja terhadap Kinerja Karyawan pada PT. Karya Murni Perkasa". Medan: Universitas Prima Indonesia.

Suwandika, I Putu Ngurah. 2019. "Pengaruh Kompetensi, Komitmen Organisasi dan Disiplin Kerja terhadap Kinerja Karyawan di UPTD Kesehatan/Puskesmas Manggis I". Denpasar: Universitas Mahasaraswati Denpasar.

Tyczkowski, Brenda dkk. 2015. "Emotional Intelligence (EI) and Nursing Leadership Styles Nurse Managers". America: University of Wisconsin Green Bay.

Umam, Khaerul. 2010. "Pengaruh Kompetensi dan Stres Kerja terhadap Kinerja Karyawan pada PT. Pioneerindo Gourmet Internasional, Tbk. Medan". Medan: Universitas Prima Indonesia.

Wibowo. 2012. "Pengaruh Kompetensi dan Beban Kerja terhadap Kinerja Pelaksanaan Asuhan Keperawatan pada Bagian Rawat Inap Rumah Sakit Umum Dr Slamet Garut". Garut: Universitas Garut. 